\title{
Video Pembelajaran Berbasis Pendekatan Kontekstual Pada Mata Pelajaran Matematika Kelas IV SD
}

\section{Ni Putu Liana Octavyanti1 ${ }^{*}$, I Gusti Agung Ayu Wulandari²}

1,2 Program Studi Pendidikan Guru Sekolah Dasar, Universitas Pendidikan Ganesha, Singaraja, Indonesia

\author{
A R T I C L E I N F O \\ Article history: \\ Received 15 Februaru 2021 \\ Revised 13 Maret 2021 \\ Accepted 10 Mei 2021 \\ Available online 25 Juni 2021

Kata Kunci:
video pembelajaran,
kontekstual, matematika.
Keywords:
learning video, contextual,
mathematics

\begin{abstract}
A B S T R A K
Rendahnya hasil belajar siswa didasari oleh minimnya media pembelajaran khususnya dalam bidang matematika, yang menyebabkan siswa sulit untuk memahami materi. Tujuan penelitian ini yaitu mengembangkan video pembelajaran berbasis pendekatan kontekstual. Jenis penelitian ini yaitu penelitian pengembangan dengan menggunakan prosedur model ADDIE. Subek uji coba penelitian ini yaitu 1 orang ahli isi pembelajaran, 1 orang ahli desain pembelajaran, 1 orang ahli media pembelajaran, 31 orang uji coba perorangan dan 6 orang uji coba kelompok kecil. Teknik yang digunakan untuk mengumpulkan data yaitu observasi, wawancara, dan kuesioner. Instrument yang digunakan dalam mengumpulkan data yaitu kuesioner. Teknik yang digunakan untuk menganalisis data yaitu analisis deskriptif kualitatif dan analisis deskriptif kuantitatif. Hasil penelitian yaitu
\end{abstract} hasil review ahli isi pembelajaran memperoleh skor 91,67\% (berkualifikasi sangat baik), hasil review ahli desain pembelajaran memperoleh skor $79,54 \%$ (berkualifikasi baik), hasil review ahli media pembelajaran memperoleh skor $93,33 \%$ (berkualifikasi sangat baik), hasil uji coba perorangan memperoleh persentase skor $93,74 \%$ (berkualifikasi sangat baik), dan hasil uji kelompok kecil memperoleh persentase skor $90,62 \%$ (berkualifikasi sangat baik). Jadi media video pembelajaran berbasis pendekatan kontekstual pada mata pelajaran matematika layak untuk digunakan. Implikasi penelitian ini yaitu media yang dikembangkan dapat digunakan oleh guru dalam meningkatkan pemahaman siswa pada mata pelajaran matematika.

\section{A B S T R A C T}

The low student learning outcomes are based on the lack of learning media, especially in the field of mathematics, which makes it difficult for students to understand the material. The purpose of this study is to develop a learning video based on a contextual approach. This type of research is development research using the ADDIE model procedure. The subjects of this research trial were 1 learning content expert, 1 learning design expert, 1 learning media expert, 31 individual trial and 6 small group trials. The techniques used to collect data are observation, interviews, and questionnaires. The instrument used in collecting data is a questionnaire. The technique used to analyze the data is descriptive qualitative analysis and descriptive quantitative analysis. The results of the research are the results of the review of learning content experts who get a score of $91.67 \%$ (very well qualified), the results of the review of learning design experts get a score of $79.54 \%$ (good qualifications), the results of the review of learning media experts get a score of $93.33 \%$ (very qualified). good), the results of individual trials obtained a percentage score of $93.74 \%$ (very well qualified), and the results of the small group test obtained a percentage score of $90.62 \%$ (very well qualified). So the learning video media based on a contextual approach to mathematics is feasible to use. The implication of this research is that the developed media can be used by teachers in improving students' understanding of mathematics.

\section{Pendahuluan}

Matematika merupakan salah satu mata pelajaran yang diajarkan pada setiap jenjang pendidikan mulai dari sekolah dasar sampai perguruan tinggi. Melalui pembelajaran matematika siswa dapat memecahkan permasalahan yang ada dalam kehidupan sehari-hari. Pelajaran matematika dipandang dapat mengembangkan kemampuan siswa untuk berpikir logis, analitis, sistematis, kritis logis, kreatif, dan

Copyright (@) Universitas Pendidikan Ganesha. All rights reserved

E-mail addresses: niputulianaoctavyanti24@undiksha.ac.id (Ni Putu Liana Octavyanti) 
bekerjasama (Ikhsan, Munzir, \& Fitria, 2017; Karno, 2020). Mata pelajaran matematika juga lebih menekankan pada kemampuan penalaran siswa (Fuadi, Johar, \& Munzir, 2016). Meskipun matematika memiliki peranan yang penting, namun kenyataanya matematika masih dianggap sebagai salah satu mata pelajaran yang sulit oleh sebagian siswa. Kesulitan belajar matematika terdapat pada kesulitan mengingat, memahami, dan menerapkan konsep matematika (Istiqlal, 2017; Tias \& Wutsqa, 2015). Sebagian siswa khususnya di SD masih beranggapan bahwa matematika merupakan mata pelajaran yang sulit untuk dipahami (Novikasari, 2017; Yuniawardani \& Mawardi, 2018). Permasalahan ini juga ditemukan pada salah satu sekolah dasar. Berdasarkan hasil wawancara dengan guru kelas IV SD No. 3 Buduk mengenai permasalahan dan kebutuhan media pembelajaran dalam mengajarkan materi mata pelajaran matematika di kelas IV, terdapat kesulitan yang dialami sebagian siswa dalam memahami materi pengukuran sudut karena materi tersebut merupakan materi yang menuntut peserta didik untuk berpikir secara abstrak. Sedangkan masih ada siswa kelas IV SD yang belum dapat berpikir secara abstrak. Materi pengukuran sudut penting dipelajari karena berkaitan dengan kehidupan sehari-hari. Selain itu, kurangnya media pembelajaran yang dapat memfasilitasi siswa dalam belajar juga berpengaruh pada kemampuan siswa dalam menangkap informasi. Apalagi materi abstrak akan sulit untuk dipahami oleh siswa sekolah dasar. Sehingga pemilihan suatu media pembelajaran untuk dapat menunjang pembelajaran dirasa sangat perlu.

Dalam proses pembelajaran, pemilihan dan penggunaan metode yang tepat dalam menyajikan suatu materi dapat membantu siswa untuk mengetahui serta memahami materi yang disajikan guru (Abdullah, 2017; Saguni, 2013). Media pembelajaran sebagai salah satu komponen sistem pembelajaran harus sesuai dengan komponen pembelajaran agar fungsinya optimal dalam kegiatan pembelajaran (Batubara \& Ariani, 2015; Isdayanti, 2020; Umbara, Sujana, \& Negara, 2020). Oleh karena itu, media pembelajaran sangat dibutuhkan dalam proses pembelajaran agar guru dapat menyampaikan materi lebih jelas, mudah dipahami, serta dapat memvisualisasikan sesuatu yang abstrak sehingga siswa lebih mudah menerima materi dengan baik (Khofiyah, Santoso, \& Akbar, 2019; Muna, Nizaruddin, \& Murtianto, 2017). Media akan mempermudah guru dalam menyampaikan materi pembelajaran (Asnur \& Ambiyar, 2018; Mediatati \& Suryaningsih, 2017). Pada masa pandemi, pembelajaran tatap muka di sekolah tidak bisa dilakukan sehingga pelaksanaan proses pembelajaran berubah menjadi pembelajaran jarak jauh (Dewi, 2020; Herliandry, Nurhasanah, Suban, \& Heru, 2020). Adanya pembelajaran jarak jauh mengharuskan guru untuk memanfaatkan teknologi informasi dan komunikasi untuk kegiatan pembelajaran. Salah satu media pembelajaran yang dapat digunakan untuk pembelajaran jarak jauh adalah video pembelajaran.

Video atau media audio visual merupakan salah satu media yang dapat menampilkan gambar bergerak dan suara. Media video merupakan media yang dapat menampilkan unsur gambar dan suara secara bersamaan pada saat mengkomunikasikan pesan atau informasi yng disampaikan (Andriyani \& Suniasih, 2021; Yendrita \& Syafitri, 2019). Video juga merupakan media yang dapat menghadirkan kenyataan di kelas (Krissandi, 2018). Video akan dapat memberikan gambaran nyata kepada peserta didik. Media video dapat memancing pembelajaran menjadi lebih hidup karena akan memunculkan rasa keingintahauan dari peserta didik. Menggunakan media video dalam pembelajaran cenderung membuat siswa untuk lebih mudah mengingat dan memahami materi pelajaran karena tidak menggunakan satu jenis indera (Purwanti, 2015; Utari, 2016). sesuatu yang bersifat abstrak menjadi terkesan nyata. Video pembelajaran sangat efektif untuk membantu proses pembelajaran, baik untuk pembelajaran secara massal, individual, maupun berkelompok (Tegeh, Simamora, \& Dwipayana, 2019; Yildiz \& Ersan, 2011). Oleh karena itu, suatu materi yang disampaikan dalam bentuk video dapat digunakan baik untuk proses pembelajaran secara langsung (tatap muka) maupun pembelajaran jarak jauh. Tujuan video pembelajaran adalah untuk memberikan penjelasan lebih menarik terkait dengan pengetahuan diberikan oleh guru kepada siswa dan informasi yang disampaikan diharapkan sesuai dengan tujuan pembelajaran (Krisna, Rinda, \& Abadi, 2013; Yudha, Pudjawan, \& Tegeh, 2017). Media video yang digunakan dalam proses belajar mengajar memiliki banyak manfaat dan keuntungan, diantaranya; video dapat menjadi pengganti alam sekitar dan dapat menunjukkan objek yang secara normal tidak dapat dilihat siswa, video dapat menggambarkan suatu proses secara tepat dan dapat dilihat secara berulang-ulang, dan mendorong peserta didik untuk meningkatkan motivasi siswa untuk tetap melihatnya (Halim, 2017; Taqiya, Nuroso, \& Reffiane, 2019).

Selain melibatkan media inovatif dalam hal ini video dalam pembelajaran, pembelajaran pada siswa sekolah dasar seharusnya dilaksanakan dengan melibatkan pengalaman siswa sehari-hari sehingga pembelajaran menjadi bermakna (Setyowati \& Mawardi, 2018; Sulastri, 2016). Adapun pendekatan yang dapat digunakan yaitu pendekatan kontekstual. Pendekatan kontekstual adalah konsep belajar yang membantu guru untuk mengaitkan antara materi yang diajarkannya dengan situasi dunia nyata siswa dan mendorong siswa membuat hubungan antara pengetahuan yang dimilikinya dengan penerapannya dalam kehidupan sehari-hari (Latief, 2014; Purwanto \& Rizki, 2015). Selain itu, pendekatan kontekstual lebih menekankan pada kemampuan siswa untuk mengkontruksi pengetahuannya dan menemukan sendiri 
sehingga siswa dapat mengeksplorasi pemikirannya sendiri dalam memperoleh pengalaman dan pengetahuan yang dipelajarinya. Pendekatan ini menekankan pada keaktifan siswa dalam menemukan pengetahuan terkait dengan materi pembelajaran. Selain itu, pendekatan kontekstual berangkat dari contoh-contoh yang dekat dengan kehidupan sehari-hari (Antara \& Aditya, 2019; Astika et al., 2020). Sehingga pembelajaran akan menjadi lebih bermakna dan tertanam erat dalam ingatan peserta didik serta tidak akan mudah terlupakan. Melalui pendekatan kontekstual siswa akan belajar lebih baik dan bermakna jika siswa "menemukan" dan "mengalami" sendiri yang dipelajarinya, bukan sekedar "mengetahuinya" (Putri, Yuliati, \& Utami, 2019).

Temuan penelitian sebelumnya menyatakan bahwa penggunaan video pembelajaran dapat meningkatkan hasil belajar siswa (Tegeh et al., 2019; Yendrita \& Syafitri, 2019). Temuan penelitian sebelumnya juga menyatakan bahwa model pembelajaran kontekstual (Hufri, Dwiridal, \& Sari, 2021; Latief, 2014). Belum adanya pengembangan video pembelajaran berbasis kontekstual pada mata pelajaran matematika. Video pembelajaran dipilih karena dapat menjelaskan suatu konsep materi yang bersifat abstrak menjadi lebih konkrit, serta dapat menjadikan pembelajaran lebih menarik. Penelitian ini bertujuan untuk menciptakan pengembangan video pembelajaran berbasis kontekstual pada mata pelajaran matematika. Kelebihan video pembelajaran ini yaitu pada video menyajikan materi yang disesuaikan dengan karakteristik siswa. Penelitian ini diharapkan dapat membantu siswa yang kesulitan memahami materi pelajaran matermatika.

\section{Metode}

Jenis penelitian ini adalah penelitian pengembangan yang mengacu pada model pengebangan model ADDIE. Model ADDIE merupakan salah satu model dengan desain pembelajaran yang tersusun sistematis dalam upaya pemecahan masalah belajar untuk menghasilkan sebuah produk yang sesuai dengan kebutuhan pembelajaran (Tegeh \& Kirna, 2010). Model ADDIE terdiri dari lima tahap, yaitu tahap analisis (analysis), tahap perancangan (design), tahap pengembangan (development), implementasi (implementation), dan tahap evaluasi (evaluation). Pengumpulan data dalam penelitian ini menggunakan metode observasi, wawancara, dan angket/kuesioner. Observasi dan wawancara digunakan untuk mengetahuai permasalahan yang sedang terjadi. Kuesioner pada penelitian ini digunakan untuk mengetahui kebutuhan siswa dan mengukur kelayakan video pembelajaran yang dikembangkan melalui review ahli isi pembelajaran, ahli desain pembelajaran, ahli media pembelajaran, uji coba perorangan dan uji coba kelompok kecil. Instrumen yang digunakan pada penelitian ini yaitu lembar kuesioner. Lembar kuesioner digunakan untuk mengumpulkan data terkait review ahli isi pembelajaran, ahli desain pembelajaran, ahli media pembelajaran, uji coba perorangan dan uji coba kelompok kecil. Adapun kisi-kisi ahli isi pembelajaran, ahli desain pembelajaran, ahli media pembelajaran, uji coba perorangan dan uji coba kelompok kecil dijabarkan pada tabel berikut.

Tabel 1. Kisi-kisi Instrumen Review Ahli Isi Pembelajaran

\begin{tabular}{cccl}
\hline No. & Aspek & & \multicolumn{1}{c}{ Indikator } \\
\hline 1. & Kurikulum & 1) & Kesesuaian materi dengan kompetensi dasar \\
& & 2) & Kesesuaian materi dengan indikator pembelajaran \\
2. & Materi & 3) & Kesesuaian materi dengan tujuan pembelajaran \\
& & 4) & Kebenaran materi \\
& & 5) & Keruntutan materi \\
& & 6) & Kelengkapan materi \\
& & 7) & Kecakupan materi \\
& 8) & Pentingnya materi \\
3. & Tata Bahasa & Materi didukung dengan media yang tepat \\
& & 10) & Tingkat kesulitan soal \\
\hline
\end{tabular}

Tabel 2. Kisi-Kisi Instrumen Review Ahli Desain Pembelajaran

\begin{tabular}{clll}
\hline No. & \multicolumn{1}{c}{ Aspek } & & \multicolumn{1}{c}{ Indikator } \\
\hline 1. & Tujuan & 1) & Kejelasan tujuan pembelajaran \\
2. & Strategi & 2) & Penyampaian materi memberikan langkah-langkah sistematis \\
& & 3) & Memberikan contoh untuk pemahaman konsep \\
& & 4) & Membantu mengingat kemampuan dan pengetahuan sebelumnya
\end{tabular}




\begin{tabular}{llll}
\hline No. & \multicolumn{1}{c}{ Aspek } & & \multicolumn{1}{c}{ Indikator } \\
\hline & & 5) & Memberikan kesempatan siswa untuk belajar mandiri \\
& & 6) & Memberikan motivasi \\
3. Evaluasi & 7) & Petunjuk penggunaan media \\
& 8) & Memberikan soal latihan untuk pemahaman konsep \\
\hline
\end{tabular}

Tabel 3. Kisi-Kisi Instrumen Review Ahli Media Pembelajaran

\begin{tabular}{clll}
\hline No. & \multicolumn{1}{c}{ Aspek } & & \multicolumn{1}{c}{ Indikator } \\
\hline 1. & Teknis & 1) & Kemudahan menggunakan media \\
& & 2) & Media dapat membantu siswa dalam pemahaman materi \\
& 3) & Video dapat diputar ulang \\
& 4) & Durasi waktu video \\
2. & Tampilan & 5) & Tampilan awal video \\
& 6) & Keterbacaan teks \\
& 7) & Penggunaan gambar mendukung materi pembelajaran \\
& 8) & Penggunaan jenis huruf, ukuran huruf dan spasi yang tepat \\
& 9) & Komposisi dan kombinasi warna yang tepat dan serasi \\
& 10) & Penggunaan animasi yang tepat \\
& 11) & Dukungan musik pengiring yang sesuai \\
& 12) & Penggunaan narasi yang sesuai \\
& 13) & Tampilan layar serasi dan seimbang \\
\hline
\end{tabular}

Tabel 4. Kisi-kisi Instrumen Review Uji Coba Perorangan dan Kelompok Kecil

\begin{tabular}{|c|c|c|}
\hline No. & Aspek & Indikator \\
\hline \multirow[t]{5}{*}{1.} & Tampilan & 1) Kemenarikan warna \\
\hline & & 2) Keterbacaan teks \\
\hline & & 3) Penggunaan jenis dan ukuran huruf yang sesuai \\
\hline & & 4) Kejelasan suara \\
\hline & & 5) Kejelasan gambar \\
\hline 2. & Motivasi & 6) Media dapat memberikan semangat dalam belajar \\
\hline \multirow[t]{2}{*}{3.} & Materi & 7) Materi mudah dipahami \\
\hline & & 8) Kejelasan uraian materi \\
\hline
\end{tabular}

Sumber: (Sudarma, Tegeh, \& Prabawa, 2015)

Metode analisis data yang digunakan dalam penelitian pengembangan ini yakni metode analisis deskriptif kualitatif dan analisis deskriptif kuantitatif. Teknis analisis deskriptif kualitatif ini digunakan untuk mengolah data hasil review ahli isi pembelajaran, ahli desain pembelajaran, dan ahli media berupa masukan, tanggapan, kritik, serta saran perbaikan yang terdapat pada angket. Hasil analisis data ini selanjutnya digunakan untuk merevisi produk yang dikembangkan. Teknik analisis kuantitatif digunakan untuk mengubah data angket yang masih berbentuk skor menjadi persentase respon dari subjek yang diteliti. Dalam penelitian ini, analisis deskriptif kuantitatif digunakan untuk mengolah data kualitatif yang diperoleh melalui angket dalam bentuk skor. Kemudian skor-skor yang diperoleh melalui angket akan dikonversi dalam bentuk persentase dari masing-masing subjek.

\section{Hasil dan Pembahasan}

\section{Hasil}

Hasil penelitian ini berupa video pembelajaran berbasis pendekatan kontekstual pada mata pelajaran matematika kelas IV SD dengan materi pengukuran sudut. Video pembelajaran ini dirancang mengacu pada kelima tahapan model ADDIE. Tahap pertama yaitu tahap analisis. Pada tahap analisis dilakukan analisis kebutuhan siswa kelas IV di SD No. 3 Buduk terkait masalah yang dihadapi dalam pembelajaran dengan menyebar angket/kuesioner kepada siswa dan melakukan wawancara dengan guru kelas IV di SD No. 3 Buduk. Tahap yang kedua yaitu tahap perancangan. Kegiatan yang dilakukan adalah merancang media pembelajaran berupa video pembelajaran berbasis pendekatan kontekstual dimulai dari mengumpulkan materi pembelajaran, kompetensi inti, kompetensi dasar, indikator pembelajaran, dan tujuan pembelajaran. Informasi yang didapatkan pada tahap analisis digunakan untuk merancang flowchat, storyboard, RPP, dan memilih software filmora untuk membuat video pembelajaran. Tahap 
ketiga yaitu tahap pengembangan. Pada tahap pengembangan, media mulai dibuat sesuai dengan rancangan flowchart dan storyboard yang telah disusun hingga menghasilkan suatu produk. Pembuatan video pembelajaran ini menggunakan bantuan powerpoint dalam membuat materi, animaker untuk pembuatan animasi guru bergerak, serta software filmora untuk pengeditan dan penggabungan komponen video serta melakukan dubbing sehingga menghasilkan produk berupa video pembelajaran.

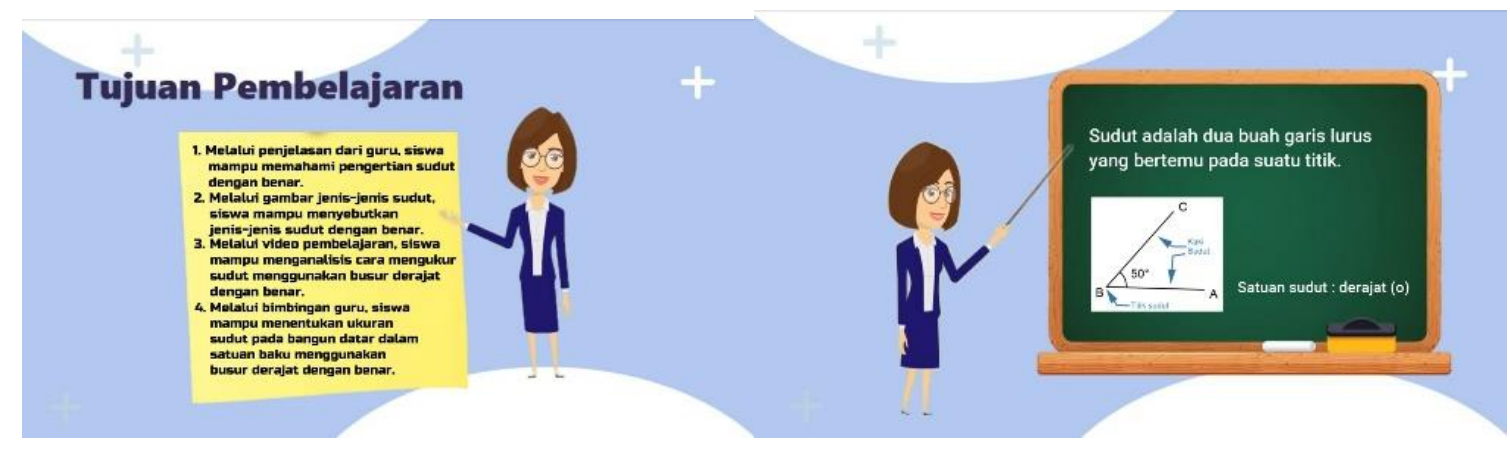

Gambar 1. Video Pembelajaran Berbasis Kontekstual

Tahap keempat yaitu tahap implementasi. Pada tahap ini dilakukan review ahli terlebih dahulu sebelum dilakukan uji coba produk kepada siswa. Review ahli dan uji coba produk terdiri dari review ahli isi pembelajaran, review ahli desain pembelajaran, review ahli media pembelajaran, uji coba perorangan, dan uji coba kelompok kecil. Hal ini dilakukan untuk mengetahui kelayakan dari media pembelajaran yang dikembangkan. Tahap kelima yaitu tahap evaluasi. Tahap ini merupakan tahap terakhir untuk melakukan evaluasi data yang telah dikumpulkan pada tahap pengembangan yang dijadikan acuan dalam mengembangkan produk. Evaluasi yang dilakukan berupa formatif. Evaluasi formatif bertujuan untuk menilai produk yang telah dikembangkan mencakup penilaian ahli, uji coba perorangan, dan kelompok kecil. Adapun hasil uji validitas produk disajikan pada tabel 5.

Tabel 5. Hasil Uji Validitas Produk

\begin{tabular}{clcc}
\hline No & Subjek Uji Coba Video Pembelajaran & Hasil Validitas (\%) & Keterangan \\
\hline 1. & Uji Ahli Isi Pembelajaran & $91,67 \%$ & Sangat Baik \\
2. & Uji Ahli Desain Pembelajaran & $79,54 \%$ & Baik \\
3. & Uji Ahli Media Pembelajaran & $93,33 \%$ & Sangat Baik \\
4. & Uji Coba Perorangan & $93,74 \%$ & Sangat Baik \\
5. & Uji Coba Kelompok Kecil & $90,62 \%$ & Sangat Baik \\
\hline
\end{tabular}

Berdasarkan hasil analisis data penilaian yang diberikan oleh ahli isi pelajaran nilai yang didapatkan yaitu 91,67\% sehingga mendapatkan kualifikasi sangat baik. Berdasarkan hasil analisis data penilaian yang diberikan oleh ahli desain pembelajaran nilai yang didapatkan yaitu 79,54\% sehingga mendapatkan kualifikasi sangat baik. Berdasarkan hasil analisis data penilaian yang diberikan oleh ahli media pembelajaran nilai yang didapatkan yaitu 93,33\% sehingga mendapatkan kualifikasi sangat baik. Berdasarkan hasil analisis data penilaian uji coba perorangan nilai yang didapatkan yaitu 93, 74\% sehingga mendapatkan kualifikasi sangat baik. Berdasarkan hasil analisis uji coba kelompok kecil mendapatkan 90,62\% sehingga mendapatkan kategori sangat baik. Dapat disimpulkan bahwa media video pembelajaran berbasis pendekatan kontekstual layak digunakan dalam pembelajaran. Hal ini disebabkan oleh beberapa faktor yaitu sebagai berikut.

Pertama, media video pembelajaran berbasis pendekatan kontekstual layak digunakan dalam pembelajaran karena dapat meningkatkan pemahaman siswa dalam belajar. Dengan adanya video pembelajaran berbasis pendekatan kontekstual pada mata pelajaran matematika ini, dapat memfasilitasi siswa dalam belajar serta memahami materi dengan baik karena adanya gambar, teks, dan animasi yang mampu menarik perhatian siswa dan memotivasi siswa untuk belajar. Video pembelajaran dikembangkan dengan mengintegrasikan nilai-nilai pendekatan kontekstual yang bertujuan untuk menjadikan pembelajaran lebih bermakna serta menciptakan suasana yang menyenangkan (Sarnoko, Ruminiati, \& Setyosari, 2016; Yuliani, Antara, \& Magta, 2017). Melalui pendekatan kontekstual materi pembelajaran dikaitkan dengan situasi dunia nyata dan mendorong siswa untuk membuat hubungan antara pengetahuan dengan penerapannya dalam kehidupan sehari-hari (Bakhri, Sari, \& Ernawati, 2019; Purwanto \& Rizki, 2015). Penelitian sebelumnya juga menyatakan pembelajaran dengan pendekatan 
kontekstual akan menjadi lebih bermakna dan tertanam erat dalam ingatan peserta didik sehingga tidak akan mudah terlupakan dan akan meningkatkan keaktivan serta motivasi siswa (Fadhilaturrahmi, 2017; Ulya, Irawati, \& Maulana, 2016). Dalam pengembangan media video pembelajaraan berbasis pendekatan kontekstual pada mata pelajaran matematika kelas IV SD, isi atau materi yang dikaji dinyatakan sesuai dengan kompetensi dasar, indikator dan tujuan pembelajaran yang telah ditetapkan. Hal ini bertujuan untuk memastikan bahwa materi yang disampaikan kepada siswa relevan dengan kebutuhannya sekaligus telah tersampaikan sebagaimana yang telah ditetapkan dalam kurikulum. Kesesuaian antara isi pembelajaran dengan tujuan pembelajaran sangat berperan penting dalam pengembangan media demi tercapainya kualitas pembelajaran yang maksimal (Siddiq et al., 2020).

Kedua, media video pembelajaran berbasis pendekatan kontekstual layak digunakan dalam pembelajaran karena dapat meningkatkan semangat siswa dalam belajar. Strategi penyampaian yang baik dengan memadukan kontekstualitas pada unsur materi pada media video pembelajaran ini berimplikasi pada penyampaian materi yang efektif dan sistematis yang memudahkan dan meningkatkan semangat siswa memahami materi pelajaran. Kualifikasi sangat baik ini secara nyata tercermin melalui kesesuaian penggunaan elemen-elemen video seperti teks, gambar, suara, warna, dan animasi. Wuryanti \& Kartowagiran (2016) mengatakan penggunaan animasi pada video akan menjadikan sajian pada video akan semakin terlihat lebih menarik dan dapat memotivasi. Melalui gambar yang bergerak, warna dan alur cerita yang menarik, dapat menarik perhatian siswa dalam mengikuti pembelajaran (Widiyasanti \& Ayriza, 2018; Wuryanti, 2016). Penyajian gambar sangat memberikan manfaat kepada pembaca, karena kejelasan gambar dapat mendukung kejelasan pesan yang terkandung dalam teks, dan hal ini dapat membangkitkan minat siswa dalam belajar (Awalia, Pamungkas, \& Alamsyah, 2019; Aziz, 2019). Hal ini menunjukkan bahwa penggunaan teks, gambar, suara, warna, dan animasi pada video pembelajaran ini sudah tepat dan sesuai, serta dapat memperjelas pesan pembelajaran yang disampaikan kepada siswa dan meningkatkan semangat siswa dalam belajar.

Temuan penelitian sebelumnya menyatakan bahwa video pembelajaran dapat memudahkan siswa dalam memahami materi yang disampaikan oleh guru (Saiboon et al., 2021; Yendrita \& Syafitri, 2019). Penelitian lainnya juga menyatakan bahwa media video pembelajaran dapat meningkatkan semangat serta hasil belajar siswa (Fadillah \& Bilda, 2019; Krisna et al., 2013). Kelebihan dari media video yang dikembangkan yaitu media video pembelajaran ini berisikan animasi yang dapat menarik perhatian siswa. Selain itu dalam pengembangan media juga mengacu pada teori desain pembelajaran. kelemahan penelitian ini yaitu penelitian ini belum dilakukan uji efektivitas, tetapi layak digunakan karena telah melewati uji validitas. Implikasi penelitian ini yaitu video pembelajaran yang dikembangkan dapat memudahkan siswa dalam belajar khususnya pada mata pelajaran matematika.

\section{Simpulan}

Media multimedia interaktif berorientasi pendekatan kontekstual materi sumber energi pada pembelajaran mendapatkan kualifikasi sangat baik sehingga layak diterapkan dalam pembelajaran. Direkomendasikan kepada guru untuk menggunakan multimedia interaktif berorientasi pendekatan kontekstual karena dapat meningkatkan minat siswa dalam belajar, sehingga akan berpengaruh pada hasil belajar IPA meningkat.

\section{Daftar Rujukan}

Abdullah, A. (2017). Pendekatan dan Model Pembelajaran yang Mengaktifkan Siswa. Jurnal Pendidikan Agama Islam, 1(1). https://doi.org/https://doi.org/10.33650/edureligia.v1i2.45.

Andriyani, N. L., \& Suniasih, N. W. (2021). Development Of Learning Videos Based On Problem-Solving Characteristics Of Animals And Their Habitats Contain in Science Subjects On 6th-Grade. Journal of Education, 5(1), 37-47. https://doi.org/http://dx.doi.org/10.23887/jet.v5i1.32314.

Antara, \& Aditya, P. (2019). Pengaruh Model Pembelajaran Kontekstual Terhadap Kemampuan Membaca Permulaan Anak. Mimbar Ilmu, 24. https://doi.org/http://dx.doi.org/10.23887/mi.v24i2.21263.

Asnur, \& Ambiyar. (2018). Penerapan Pembelajaran Menggunakan Media Video Pada Mata Kuliah Tata Boga II. Jurnal Mimbar Ilmu, 23(3). https://doi.org/http://dx.doi.org/10.23887/mi.v23i3.16435.

Astika, R. T., Astra, I. M., Makmuri, Sumarni, S., Andika, W. D., \& Wahyudi, A. (2020). Video Pembelajaran Kontekstual Mendukung Hasil Tes Matematika Siswa Sekolah Dasar. 127-136.

Awalia, I., Pamungkas, A. S., \& Alamsyah, T. P. (2019). Pengembangan Media Pembelajaran Animasi Powtoon pada Mata Pelajaran Matematika di Kelas IV SD. Jurnal Matematika Kreatif-Inovatif, 10(1). https://doi.org/https://doi.org/10.15294/kreano.v10i1.18534.

Aziz, Z. (2019). Fluxus Animasi dan Komunikasi di Era Media Baru Digital. Channel Jurnal Komunikasi, 7(1), 49-58. https://doi.org/http://dx.doi.org/10.12928/channel.v7i1.13017. 
Bakhri, S., Sari, A. F., \& Ernawati, A. (2019). Kualitas Pembelajaran Kontekstual Siswa IPS Materi Program Linier yang Memiliki Kecemasan Belajar Matematika. Kreano Jurnal Matematika Kreatif-Inovatif, 10(2). https://doi.org/https://doi.org/10.15294/kreano.v10i2.19061.

Batubara, H. H., \& Ariani, D. N. (2015). Model Pengembangan Media Pembelajaran Adaptif di Sekolah dasar. Jurnal Madrasah Ibtidaiyah, 5(1), 33-46.

Dewi. (2020). Dampak COVID-19 terhadap Implementasi Pembelajaran Daring di Sekolah Dasar. Jurnal Edukatif Ilmu Pendidikan, 2(1). https: //doi.org/https://doi.org/10.31004/edukatif.v2i1.89.

Fadhilaturrahmi. (2017). Peningkatan Hasil Belajar Siswa pada Materi Jaring-Jaring Balok dan Kubus dengan Pendekatan Contextual Teaching and Learning (CTL) Siswa Kelas IV SDN 05 Air Tawar Barat. Jurnal Basicedu, 1(1), 1-9. https://doi.org/10.31004/basicedu.v1i1.9.

Fadillah, A., \& Bilda, W. (2019). Pengembangan video pembelajaran matematika berbatuan aplikasi sparkoll videoscribe. Jurnal Gantang, 4(2), 177-182.

Fuadi, R., Johar, R., \& Munzir, S. (2016). Peningkatkan Kemampuan Pemahaman dan Penalaran Matematis melalui Pendekatan Kontekstual. Jurnal Didaktik Matematika, 3(1), 47-54. https://doi.org/10.24815/jdm.v3i1.4305.

Halim, D. (2017). Pengembangan Video Pembelajaran IPA Pada Materi Pencemaran Dan Kerusakan Lingkungan. Jurnal Pendidikan Sains Indonesia, 5(2), 108-114. https://doi.org/https://doi.org/10.24815/jpsi.v5i2.9825.

Herliandry, L. D., Nurhasanah, Suban, M. E., \& Heru, K. (2020). Pembelajaran Pada Masa Pandemi Covid-19. Jurnal Teknologi Pendidikan, 22(1), 65-70. https://doi.org/https://doi.org/10.21009/jtp.v22i1.15286.

Hufri, H., Dwiridal, L., \& Sari, S. Y. (2021). Peningkatan Kompetensi Guru-Guru IPA SMP/MTsN Lubuk Sikaping melalui Pelatihan Pengembangan Bahan Ajar Berbasis Kontekstual. Jurnal Pengabdian Kepada Masyarakat, 6(1). https://doi.org/https://doi.org/10.30653/002.202161.502.

Ikhsan, M., Munzir, S., \& Fitria, L. (2017). Kemampuan Berpikir Kritis dan Metakognisi Siswa Dalam Menyelesaikan Masalah Matematika Melalui Pendekatan Problem Solving. Jurnal Aksioma, 6(2), 234-245. https://doi.org/http://dx.doi.org/10.24127/ajpm.v6i2.991.

Isdayanti, D. (2020). Pengembangan Media Pembelajaran Audio Visual Berbasis Adobe Flash Pada Materi Daur Hidup Hewan. JIPP (Jurnal Ilmiah Pendidikan Dan Pembelajaran, 4(2), 390-406. https://doi.org/http://dx.doi.org/10.23887/jipp.v4i2.27320.

Istiqlal, M. (2017). Pengembangan Multimedia Interaktif dalam Pembelajaran Matematika. Jurnal Ilmiah Pendidikan Matematika, 2(2), 43-3. https://doi.org/https://doi.org/10.26877/jipmat.v2i1.1480.

Karno. (2020). Peningkatan Hasil Belajar Materi Pengukuran Sudut Melalui Index Card Match Bagi Siswa Kelas IV Pada Semester 2 Tahun Pelajaran 2018/2019. Jurnal Pendidikan Cerdik Cendekia, 01(03), 177-188.

Khofiyah, H. N., Santoso, A., \& Akbar, S. (2019). Pengaruh Model Discovery Learning Berbantuan Media Benda Nyata terhadap Kemampuan Berpikir Kritis dan Pemahaman Konsep IPA. Jurnal Pendidikan: Teori, Penelitian, Dan Pengembangan, 4(1), 61-67. https://doi.org/http://dx.doi.org/10.17977/jptpp.v4i1.11857.

Krisna, N. L. P. G., Rinda, \& Abadi, I. B. G. S. (2013). Pengaruh Model Pembelajaran Kuantum berbantuan Media Video Kontekstual terhadap Hasil Belajar IPA Siswa di SDN 2 Dangin Puri. MIMBAR PGSD Undiksha, 1(1). https://doi.org/http://dx.doi.org/10.23887/jjpgsd.v1i1.1261.

Krissandi, A. D. S. (2018). Pengembangan Video Tematik Sebagai Pengantar Pembelajaran Kurikulum 2013 di Sekolah Dasar. Premiere Educandum : Jurnal Pendidikan Dasar Dan Pembelajaran, 8(1), 68-77. https://doi.org/10.25273/pe.v8i1.2233.

Latief, H. (2014). Pengaruh Pembelajaran Kontekstual Terhadap Hasil Belajar (Studi Eksperimen Pada Mata Pelajaran Geografi Kelas VII DI SMPN 4 Padalarang. Jurnal Geografi, 14(2). https://doi.org/https://doi.org/10.17509/gea.v14i2.3395.

Mediatati, N., \& Suryaningsih, I. (2017). Penggunaan Model Pembelajaran Course Review Horay Dengan Media Flipchart Sebagai Upaya Meningkatkan Hasil Belajar PKn. Jurnal Ilmiah Sekolah Dasar, 1(2). https://doi.org/http://dx.doi.org/10.23887/jisd.v1i2.10146.

Muna, H., Nizaruddin, \& Murtianto, Y. H. (2017). Pengembangan Video Pembelajaran Matematika Berbantuan Macromedia Flash 8 Dengan Pendekatan Kontekstual Pada Materi Program Linier Kelas XI. Aksioma, 8(2), 9-18. https://doi.org/10.26877/aks.v8i2.1686.

Novikasari, I. (2017). Hubungan Antara Prestasi Belajar Dan Tingkat Kecemasan Matematika Pada Mahasiswa Calon Guru SD/MI. Jurnal Aksioma, https://doi.org/https://doi.org/10.24127/ajpm.v5i2.671.

Pengembangan Media Video Animasi untuk Meningkatkan Motivasi Belajar dan Karakter Kerja Keras Siswa Sekolah Dasar. (2016). Jurnal Pendidikan Karakter, 6(2). https://doi.org/https://doi.org/ 
10.21831/jpk.v6i2.12055.

Purwanti, B. (2015). Pengembangan Media Video Pembelajaran Matematika dengan Model Assure. Jurnal $\begin{array}{llll}\text { Kebijakan Dan Pengembangan } & \text { 3(1), }\end{array}$ https://doi.org/https://doi.org/10.22219/jkpp.v3i1.2194.

Purwanto, Y., \& Rizki, S. (2015). Pengembangan Bahan Ajar Berbasis Kontekstual Pada Materi Himpunan Berbantu Video Pembelajaran. AKSIOMA Journal of Mathematics Education, 4(1), 67-77. https://doi.org/10.24127/ajpm.v4i1.95.

Putri, F. A., Yuliati, S. R., \& Utami, N. C. M. (2019). Pengembangan Multimedia Interaktif Berbasis Pendekatan Kontekstual dalam Pembelajaran Matematika di Sekolah Dasar. Dinamika Sekolah Dasar, 9(2), 1-9.

Saguni, F. (2013). Efektivitas Metode Problem Based Learning, Cooperative Learning Tipe Jigsaw, Dan Ceramah Sebagai Problem Solving Dalam Matakuliah Perencanaan Pembelajaran. Cakrawala Pendidikan, 1(2). https://doi.org/https://doi.org/10.21831/cp.v0i2.1478.

Saiboon, I. M., MSurg, Nurmaimun, Noriani, Shamsuddin, N. S., \& Johar, M. (2021). Effectiveness of SelfDirected Small-Group-Learning Against Self-Directed Individual-Learning Using SelfInstructional-Video in Performing Critical Emergency Procedures Among Medical Students in Malaysia: A Single-Blinded Randomized Controlled Study. Clinical Simulation in Nursing, 56(1). https://doi.org/https://doi.org/10.1016/j.ecns.2021.02.006.

Sarnoko, Ruminiati, \& Setyosari, P. (2016). Penerapan Pendekatan Savi berbantuan Video Pembelajaran untuk Meningkatkan Aktivitas dan Hasil Belajar IPS Siswa Kelas IV SDN 1 Sanan Girimarto Wonogiri. Jurnal Pendidikan, 7(1). https://doi.org/http://dx.doi.org/10.17977/jp.v1i7.6524.

Setyowati, N., \& Mawardi. (2018). Sinergi Project Based Learning dan Pembelajaran Bermakna Untuk Meningkatkan Hasil Belajar Matematika. Scholaria, 8(3), 253-263. https://doi.org/http://doi.org/10.24246/j.js.2018.v8.i3.p253-263.

Siddiq, Y. I., Sudarma, I. K., \& Simamora, A. H. (2020). Pengembangan Animasi Dua Dimensi pada Pembelajaran Tematik untuk Siswa Kelas III Sekolah Dasar. Jurnal Edutech Undiksha, 8(2), 49-63. https://doi.org/10.23887/jeu.v8i2.28928.

Suartama, I. K. (2016). Evaluasi dan Kriteria Kualitas Multimedia Pembelajaran. Singaraja: Universitas Pendidikan Ganesha.

Sudarma, I. K., Tegeh, I. M., \& Prabawa, D. G. A. P. (2015). Desain Pesan Kajian Analisis Desain Visual Teks dan Image. Yogyakarta: Graha Ilmu.

Sulastri, A. (2016). Penerapan Pendekatan Kontekstual dalam Pembelajaran Matematika untuk Meningkatkan Pemahaman Konsep Matematis Siswa Sekolah Dasar. Jurnal Pendidikan Guru Sekolah Dasar, 1(1), 156-170. https://doi.org/10.17509/jpgsd.v1i1.9068.

Taqiya, Nuroso, \& Reffiane. (2019). Pengaruh Model Pembelajaran Terpadu Tipe Connected Berbantu Media Video Animasi. Mimbar PGSD Undiksha, 7(3), 289-295. https://doi.org/http://dx.doi.org/10.23887/jjpgsd.v7i3.19492.

Tegeh, I. M., \& Kirna, I. M. (2010). Metode Penelitian Pengembangan Pendidikan. Singaraja: Undiksha.

Tegeh, Simamora, \& Dwipayana. (2019). Pengembangan Media Video Pembelajaran Dengan Model Pengembangan 4D Pada Mata Pelajaran Agama Hindu. Jurnal Mimbar Ilmu, 24(2), 158-166. https://doi.org/http://dx.doi.org/10.23887/mi.v24i2.21262.

Tias, A. A. W., \& Wutsqa, D. U. (2015). Analisis Kesulitan Siswa SMA Dalam Pemecahan Masalah Matematika Kelas XII IPA di Kota Yogyakarta. Jurnal Reset Pendidikan Matematika, 2(1). https://doi.org/https://doi.org/10.21831/jrpm.v2i1.7148.

Ulya, I. F., Irawati, R., \& Maulana. (2016). Peningkatan Kemampuan Koneksi Matematis dan Motivasi Belajar Siswa Menggunakan Pendekatan Kontekstual. Jurnal Pena Ilmiah, 1(1), 121-130. https://doi.org/10.23819/pi.v1i1.2940.

Umbara, Sujana, I. W., \& Negara, I. G. A. O. (2020). Model Pembelajaran Problem Based Learning Berbantuan Media Gambar Seri BerpengaruhTerhadap Kompetensi Pengetahuan IPS Siswa. Jurnal Mimbar Ilmu, 25(2), 174-186. https://doi.org/http://dx.doi.org/10.23887/mi.v25i2.25154.

Utari, R. (2016). Kontribusi Motivasi Belajar Dan Kebiasaan Belajar Siswa Kelas 1 Teknik Audio Video Terhadap Hasil Belajar Pada Mata Diklat Pkdle Di Smk N 1 Padang. Jurnal Ilmiah Pendidikan $\begin{array}{llll}\text { Teknik } \quad \text { Elektro, } & \text { 1(oktober }\end{array}$ https://doi.org/http://dx.doi.org/10.30870/volt.v1i2.2877.

Widiyasanti, M., \& Ayriza, Y. (2018). Pengembangan Media Video Animasi untuk Meningkatkan Motivasi Belajar dan Karakter Tanggung Jawab Siswa Kelas V. Jurnal Pendidikan Karakter, 8(1), 1-16. https://doi.org/10.21831/jpk.v8i1.21489.

Wuryanti. (2016). Pengembangan Media Video Animasi untuk Meningkatkan Motivasi Belajar dan Karakter Kerja Keras Siswa Sekolah Dasar. Jurnal Pendidikan Karakter, 6(2). 
https://doi.org/.https://doi.org/ 10.21831/jpk.v6i2.12055.

Yendrita, \& Syafitri. (2019). Pengaruh Penggunaan Media Video Pembelajaran Terhadap Hasil Belajar Biologi. Jurnal Pendidikan Biologi Dan Sains, 2(1). https://doi.org/https://doi.org/10.31539/bioedusains. v2i1.620.

Yildiz, S., \& Ersan, Y. (2011). A study on pc - video games in terms of the space awareness from childhood

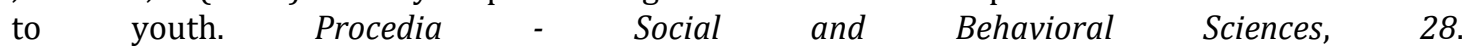
https://doi.org/https://doi.org/10.1016/j.sbspro.2011.11.145.

Yudha, Pudjawan, \& Tegeh. (2017). Pengembangan Video Matembang Sekar Alit Berbasis Model Direct Instruction DI SMP Negeri 5 SINGARAJA. Jurnal Edutech Undiksha, 5(1), 19-27. https://doi.org/http://dx.doi.org/10.23887/jeu.v5i1.20198.

Yuliani, Antara, \& Magta. (2017). Pengaruh Video Pembelajaran Terhadap Kemampuan Berhitung Permulaan Anak Kelompok B Di Taman Kanak-Kanak. Jurnal Pendidikan Anak Usia Undiksha, 5(1), 96-106. https://doi.org/http://dx.doi.org/10.23887/paud.v5i1.11309.

Yuniawardani, V., \& Mawardi. (2018). Peningkatan Hasil Belajar Pada Pembelajaran Matematika Dengan Model Problem Based Learning Kelas IV SD. Jurnal Riset Teknologi Dan Inovasi Pendidikan, 1(2), 24-32. https://doi.org/https://doi.org/10.31764/justek.v1i1.416. 